\title{
Membangun Karekter Generasi Muda Melalui Olahraga Karate Di Dojo Buana Impian Ii Kelurahan Tembesi- Kecamatan Sagulung-Kota Batam
}

\author{
Sunarto Wage ${ }^{*}$, Mhd. Johan ${ }^{2}$, Syahril Effendi ${ }^{3}$ \\ ${ }^{1,3}$ Jurusan/Program Studi Akuntansi, Fakultas Ilmu Sosial dan Humaniora \\ ${ }^{2}$ Jurusan/Program Studi Bahasa dan Sastra Inggris, Fakultas Ilmu Sosial dan Humaniora \\ ${ }^{1,2,3}$ Universitas Putera Batam, Jalan R. Soeprapto Muka Kuning, Kibing, Kec. Batu Aji, \\ Kota Batam, Kepulauan Riau 29434 \\ *e-mail : sunarto@puterabatam.ac.id
}

Informasi Artikel

Diterima Redaksi: 25 Desember 2021

Revisi Akhir: 29 Desember 2021

Diterbitkan Online: 15 Januari 2022

Kata Kunci:

Membangun; Karekter; Generasi Muda; Melalui Olahraga; Karate

\section{PENDAHULUAN}

Karakter adalah seperangkat sifat yang selalu dikagumi sebagai tanda-tanda kebaikan, kebajikan dan kematangan moral seseorang. Secara etimologi, istilah karakter berasal dari bahasa Latin character, yang berarti watak, tabiat, sifat-sifat kejiwaan, budi pekerti, kepribadian dan akhlak. Karakter identik dengan akhlak, etika, dan moral, sehingga karakter merupakan nilainilai perilaku manusia yang universal meliputi seluruh aktivitas manusia, baik dalam rangka berhubungan dengan Tuhan, dengan dirinya, dengan sesama manusia, maupun dengan lingkungannya, yang terwujud dalam pikiran, sikap, perasaan, perkataan, dan perbuatan berdasarkan

\section{Abstrak}

Latihan olahraga karate di laksanakan setiap hari Sabtu dan hari Minggu setiap minggunya yang berlokasi di Fasum RT 002 RW 028 Perumahan Buana Impian 2 mulai jam 16.00 - $18.00 \mathrm{Wib}$. Peserta latihaj olahraga karate saat ini berjumlah 46 siswa yang berasal dari sekitar perumahan Buana 2 seperti; Perumahan Buana Impian 1, Perubahan Bumi Sakinah, Perumahan Citra Laguna, dan Perumahan Bukit Pertama. Peserta Latihan olahraga karate sangat antusias mengikuti latihan setiap minggunya dan orang tuanya juga sangat mendukung kegiatan olahraga karate yang diikuti oleh putra dan putrinysa. Latihan olahraga karate di Perumahan Buana Impian 2 sudah berjalan 2 tahun yang di mulai pada tanggal 13 November 2019 dalam kelompok kegiatan olahraga 'DOJO BUANA IMPIAN 2 - ASKI KEPRI'. Pengabdian kepada masyarakat kepada siswasiswa karate di Perumahan Buana Imian 2 ini bertujuan untuk memberi bekal kepada siswa tentang pentingnya olahraga karate untuk membentuk karakter yang baik di samping untuk melatih olahraga karate itu. Teknik pengabdian ini dilaksanakan setiap hari Sabtu dan hari Minggu kepada siswa-siswa karate di Perumahan Buana Impian 2. Setelah mengikuti kegiatan olahraga karate diharapkan siswa-siswa memperoleh prestasi dibidang olahraga karate dan memiliki karakter yang baik.

norma-norma agama, hukum, tatakrama, budaya, dan adat istiadat [3].

Ada beberapa karakter manusia menurut motivasinya:

a) Achievement Motivation. Manusia yang memiliki karakter dengan motivasi seperti ini selalu berusaha untuk mendapat prestasi yang terbaik. Ciricirinya adalah mengurung diri di kamar untuk selalu belajar serta kurang peka terhadap lingkungan [4].

b) Popularity Motivation. Manusia dengan karakter seperti ini selalu mengutamakan hubungan sosial, rela meninggalkan kepentingan pribadinya untuk urusan pertemanan. Cirinya adalah pada umumnya menghabiskan 
waktu berjam-jam demi membina hubungan sosial yang baik [5].

c) Power Motivation. Manusia dengan karakter ini cenderung bersifat pemimpin, selalu ingin lebih pandai, kuat, dan berkuasa [6].

Sembilan karakter yang dapat mengantarkan kesuksesan seseorang menurut [1] adalah sebagai berikut: (1) keberanian, (2) kesetiaan, (3) kerajinan, (4) kerendahan hati, (5) kehematan, (6) kejujuran, (7) kelemah-lembutan, (8) penghormatan, dan (9) berterima kasih. Pembentukan karakter generasi muda dapat dilakukan salah satunya melalui olahraga. Dengan olahraga kita bisa kembangkan karakter bangsa, sportivitas sekaligus merekatkan persatuan bangsa. Atas dasar tersebut, semua komponen bangsa harus memberikan andil dalam memajukan olahraga nasional khususnya olah raga karate [7].

Menurut [2], dalam melaksanakan pembentukan karakter, generasi muda memiliki 3 peran penting yaitu:

a) Sebagai pembangun kembali karakter bangsa (charater builder). Peran generasi muda adalah membangun kembali karakter positif bangsa. Hal ini tentunya sangat berat, namun esensinya adalah adanya kemauan keras dan komitmen dari generasi muda untuk menjunjung nilai-nilai moral diatas kepentingan-kepentingan sesaat sekaligus upaya kolektif untuk menginternalisasikannya.

b) Sebagai pemberdaya karakter (character enabler). Generasi muda dituntut untuk mengambil peran sebagai pemberdaya karakter. Bentuk praktisnya adalah kemauan dan hasrat yang kuat dari generasi muda untuk menjadi role model dari pengembangan karakter bangsa yang positif.

c) Sebagai perekayasa karakter (character engineer). Peran yang terakhir ini menuntut generasi muda untuk terus melakukan pembelajaran. Harus diakui bahwa pengembangan karakter positif bangsa bagaimanaupun juga menuntut adanya modifikasi dan rekayasa yang tepat disesuaikan dengan perkembangan jaman. Dalam hal ini peran generasi muda sangat diharapkan oleh bangsa, karena ditangan merekalah proses pembelajaran dapat berlangsung dalam kondisi yang paling produktif [8].

Masatoshi Nakayama, salah seorang murid Gichin Funakoshi, turut mempopulerkan beladiri karate. Dalam mengajarkan karate, beliau menggunakan metode yang sistematis sehingga dapat lebih diterima oleh nalar. Karate juga dapat dipertandingkan seperti olahraga lain dengan tetap tidak mengabaikan unsur beladirinya, asal dilakukan dengan benar. Karate adalah seni beladiri yang berasal dari Jepang pada tahun 1869 di Okinawa yang pertama kalinya memperagakan Tea atau Okinawa-Te. Pada tahun 1929 banyak tokoh-tokoh yang dari Okinawa membawa alirannya masing-masing ke Jepang. Seperti Kenwa Mabuni menamakan alirannya Shitoryu, Choyun Miyagi menamakan alirannya Gojuryu, Ghicin Funakoshi menamakan alirannya Shotokan dan Othsuka Hironori menamakan alirannya Wadoryu [9].

Sejarah karate di Indonesia sendiri bukan dibawa oleh para tentara Jepang, namun karate di Indonesia masuk karena dibawa oleh para mahasiswa yang pulang ke Tanah air seusai menyelesaikan pendidikannya di Jepang. Pada tahun 1963 beberapa mahasiswa Indonesia antara lain: Baaud AD Adikusuma, Karianto Djojonegoro, Mochtar Ruskan, dan Ottoman Nuh mendirikan dojo di Jakarta. Mereka inilah yang mula-mula memperkenalkan karate (aliran Shotokan) di Indonesia, dan selanjutnya mereka membentuk wadah yang mereka namakan Persatuan Olahraga Karate Indonesia (PORKI) yang diresmikan pada tanggal 10 Maret 1964 di Jakarta [10].

Kewajiban dan ketentuan yang berlaku di lingkungan Karate [11]

a) Pakaian karate (Karate-gi) harus berwarna putih dan tidak dibenarkan mamakai pakaian karate yang bercorak warna lain. Murid harus selalu menjaga dirinya dan segala perlengkapan latihan, antara lain ; Karate-gi, pelindung kaki, dan sarung tangan dalam keadan bersih dan tidak bau.

b) Hanya karate-gi bersih yang dikenakan dan jangan berkesan jorok. Karategi yang robek harus segera dijahit kembali. Membiarkan perlengkapan latihan dan karate-gi kusut secara terus menerus, memberi kesan tidak bersemangat. 
c) Panjang lengan karate-gi tidak boleh menutupi pergelangan tangan dan harus menutupi siku, tidak dibenarkan dilipat.

d) Panjang celana karate-gi tidak boleh menutupi pergelangan kaki dan harus menutupi lutut, tidak dibenarkan dilipat.

e) Badge perguruan harus dan wajib dipasang di dada sebelah kiri sebagai identitas organisasi dan memasang badge FORKI di dada sebelah kanan.

f) Pada acara-acara khusus seperti PON, PORDA atau kejuaraan antar perguruan tinggi dibenarkan mamakai lambang daerah/departemen/instansi sebagai pangganti lambang perguruan di dada sebelah kiri.

g) Pemakaian sabuk karate harus sesuai dengan ketentuan yang telah ditetapkan dewan guru perguruan tentang tingkat kyu dan warna sabuk.

h) Panjang ujung sabuk karate setelah diikatkan di pinggang tidak boleh melebihi atau melampaui lutut.

i) Setiap anggota karate baik pelatih maupun atlit harus berpakaian karate selama mengikuti latihan karate, tanpa pakaian karate tidak dibenarkan melatih maupun mengikuti latihan karate.

j) Jangan membetulkan karate-gi atau letak sabuk karate/obi selama Latihan sebelum diijinkan pelatih. Apabila mau membetulkan karate-gi/obi, lakukan dengan cepat dan tidak berisik sambil menghadap ke belakang.

k) Para murid dilarang meninggalkan dojo tanpa ijin dari pelatih. Bila ada hal yang mendesak dan harus berangkat dengan segera, lakukan dengan sikap sopan dan jelaskan keperluannya dengan cepat.

1) Untuk menghindari kemungkinan cedera, para murid dilarang mengenakan perhiasan, jam tangan atau perhiasan lain yang tajam selama latihan, kacamata berukuran diperkenankan, tetapi selama Kumite, sebaiknya dilepaskan atau menggunakan kontak lensa.

m) Secara tradisi, dojo adalah tempat yang dihormati, dianggap suci, oleh karena itu para murid seharusnya tidak mengenakan topi atau sejenisnya atau menggunakan bahasa kotor di lingkungan sekolah karate dan dojo. Juga jangan mengenakan sepatu/sandal memasuki areal dojo. Tidak ada makanan, minuman dan rokok yang diijinkan di sekitar lingkungan perguruan karate.

n) Para murid harus selalu ikut membantu menjaga dan membersihkan dojo sebagai tempat yang khusus dan disayangi sebelum dan setelah selesai latihan.

o) Cara memberikan latihan karate diperagakan langsung (praktek) dan bukan diberikan dengan cara tertulis.

p) . Materi latihan pada olah raga beladiri karate hanya satu macam yang dibagi dalam (3) tiga bagian, yaitu: (a) Gerakan
Dasar
(Kihon),

Pertarungan/perkelahian (Kumite), (c) Jurus (Kata). Yang ketiganya merupakan satu kesatuan yang tidak dapat dipisahkan

a) Olahraga berfungsi sebagai sarana untuk: (1) penyaluran emosi, (2) penguatan identitas, (3) kontrol sosial, (4) sosialisasi, (5) agen perubahan, (6) penyaluran kata hati, dan (7) mencapai keberhasilan [12].

\section{METODE}

Pengabdian kepada masyarakat dimaksudkan untuk memberikan pelatihan olahraga karate dan memberikan pembinaan tentang membentuk karakter siswa-siswa Dojo Buana Impian 2. Dengan mengikuti pengabdian ini warga perumahan Buana Imian 2 dan sekitarnya bisa mengikuti olahraga karate yang dilaksanakan setiap minggunya.. Permasalahan utama yang dihadapi oleh Dojo Buana Impian 2 adalah : (1) Ada sebagian anak-anak yang belum tertarik untuk mengikuti olahraga karate, padahal olahraga karate sangat bagus untuk kesehatan dan menunjung prestasi di sekolah, (2) perlengkapan untuk menunjang kegiatan olahraga karate masih sangat terbatas dibandingkan dengan siswa yang mengikuti olahraga karate, (3) siswa-siswa Dojo Buana Impian 2 perlu dibimbing tentang karakter yang baik disamping olahraga karate itu sendiri.(4) perlunya dukungan orang tua secara maksimal sehingga kegiatan olahraga karate lebih baik lagi kedepaannya. Pelaksanaan pengabdian kepada masyakat ini dilaksanakan dengan beberapa tahapan diantaranya adalah sebagai berikut: 
a) Sebelum dilakukan pengabdian kepada masyarakt terlebih dahulu dilakukan survey di lokasi untuk mengetahui kondisi dan permasalahan yang dihadapi oleh Dojo Buana Impian 2 di RW 028.

b) Memberikan latihan orahraha karate setiap hari Sabtu dan Minggu dengan kegiatan sebagai berikut; (1) berdo'a terlebih dahulu sebelum latihan, (2) Pemasanasan, (3) Gerakan dasar (Kihon), (4) Pertarungan/perkelahian (Kumite), (5) Jurus (Kata), (6) ceramah/pembinaan, (7) pendinginan, dan (8) berdo'a, selesai

c) Semua siswa Dojo Buana Impian 2 mengikuti kegiatan kenaikan tingkat yang dilaksanakan setiap 4 bulan yang di ikuti oleh Dojo seluruh Kota Batam.

d) Siswa-siswa Dojo Buana Impian 2 mengikuti berbagai kejuaraan karate yan diadakan di Kota Batam maupun tingkat Provinsi Kepulauan Riau.

\section{HASIL DAN PEMBAHASAN}

Pengabdian kepada masyarakat di Dojo Buana Impian 2 RW 028 Kelurahan Tembesi berjalan lancar. dan siswa siswa olahraga karate mengikuti latihan dengan sungguh-sungguh. Beberapa manfaat atau hasil yang diperoleh setelah mengikuti latihan olahraga karate di Dojo Buana Impian 2 adalah sebagai berikut:

a) Terpeliharanya kesehatan dan kebersihan siswa-siswa Dojo Buana Impian 2 dan terhindar dari sakit.

b) Meningkatnya disiplin siswa-siswa Dojo Buana Impian 2 dalam kehidupan sehari-hari dan terhindarnya kegiatankegiatan yang kurang bermanfaat untuk dirinya maupun masyarakat dilingkungannya.

c) Meningkatnya prestasi disekolah siswasiswa Dojo Buana Impian 2 dibidang akademik maupun olah raga khususnya karate.

\section{KESIMPULAN}

Berdasarkan hasil kegiatan yang telah dilakukan dapat disimpulkan bahwa kegiatan pengabdian kepada masyarakat berupa latihan olahraga karate di Dojo Buana Impian 2 berhasil dengan baik. Siswa-siswa Dojo Buana Impian 2 mengikuti latihan olahraga karate setiap hari sabtu dan hari minggu dengan sungguhsungguh dan penuh semangat.

\section{SARAN}

Pengabdian kepada masyarakat ini sangat berfaat bagi masyarakat di Perumahan Buana Impian 2 RW 028 dan sekitarnya khususnya untuk anak-anak dan pengabdian ini bisa berjalan terus sehingga mampu menghasilkan atlet-atlet karate di tingkat Kota Batam dan tingkat Provinsi Kepulauan Riau bahkan Nasional di olahraga Karate dari Dojo Buana Impian 2.

\section{UCAPAN TERIMA KASIH}

Terima kasih kepada LPPM Universitas Putera Batam, Ketua RW 028 Perumahan Buana Impian 2 dan Pelatih dan peserta Karate di Perumahan Buana Impian 2.

\section{REFERENSI}

[1]. Ahmad Muzamil (2015). Pendidikan karakter melalui kegiatan ekstrakulikuler karate BKC pada siswa MI Nurussibyan. Skripsi Universitas Islam Negeri Walisongo Semarang

[2]. Dhedhy Yuliawan (2016). Pembentukan Karakter Anak dengan Jiwa Sportif Melalui Pendidikan Jasmani Olahraga dan Kesehatan. Jurnal Sportif Issn : 2477 - 3379 Vol. 2 No. 1 Mei 2016.

[3]. Danardono. Sejarah, Etika dan Filosofi Seni Beladiri Karate.

[4]. https://www.dosenpendidikan.co.id/k arakter-adalah/

[5]. https://123dok.com/title/sejarahetika-dan-filosofi-seni-beladiri-karate

[6]. Indra Darma Sitepu (2017). Pembentukan karakter melalui partisipasi dalam olahraga. Jurnal Pedagogik Olahraga, Volume 03, Nomor 02, Juli - Desember 2017.

[7]. Kresna Agung Pradana (2018). Penanaman Karakter Disiplin dan Percaya Diri Melalui Ekstrakurikuler Karate Di Sd Negeri 2 Tlogorandu. Skripsi Program Studi Pendidikan Guru Sekolah Dasar Fakultas Keguruan Dan Ilmu Pendidikan Universitas Muhammadiyah Surakarta

[8]. Osman Nur Matutu, Nurliani, dan Fahrizal (2019). Kontribusi Kecepatan Reaksi Tangan Dan 
Ketepatan Terhadap Kemampuan Pukulan Giaku Tsuki Pada Cabang Olahraga Karate Inkado Di Ranting Kota Makassar. E- Jurnal Olahraga Karate Fakultas Ilmu Keolahragaan, Universitas Negeri Makassar.

[9]. Sumaryanto (2012). Pembentukan Karakter Melalui Olahraga. Diskusi Kajian Olahraga yang diselenggarakan oleh BEM FIK di FIK UNY 19 April 2012.

[10]. Samrin (2016). Pendidikan Karakter (Sebuah Pendekatan Nilai). Jurnal AlTa'dib Vol. 9 No. 1, Januari-Juni 2016.

[11]. Winarno (2012). Pengembangan Karakter Bangsa Melalui Pendidikan Jasmani \& Olahraga. Pidato Pengukuhan Guru Besar dalam Bidang Ilmu Keolahragan pada Fakultas Ilmu Keolahragaan Disampaikan dalam Sidang Senat Terbuka Universitas Negeri Malang (UM) Pada Tanggal 5 Desember 2012.

[12]. Yolanda Syahputra, 2015 Kontribusi Panjang Tungkai dan Fleksibilitas Sendi Panggul Terhadap Hasil Tendangan Ushiro Geri Dalam Karate. Universitas Pendidikan Indonesia | repository.upi.edu | perpustakaan.upi.edu 